\title{
PERAN MEDIA MASSA DALAM PEMBENTUKAN IDENTITAS NASIONAL DI WILAYAH PERBATASAN INDONESIA-TIMOR LESTE
}

\author{
Ernalem Bangun \\ Universitas Pertahanan Indonesia
}

\begin{abstract}
Abstrak. Media massa memiliki peran penting dalam pembentukan identitas nasional, khususnya di Indonesia yang memiliki wilayah berupa kepulauan. Namun demikian, kurang meratanya ketersediaan akses ke media massa di seluruh wilayah Indonesia masih menjadi kendala bagi efektivitas peran media massa tersebut. Tulisan ini berupaya menyajikan gambaran empiris mengenai akses media massa di daerah perbatasan dalam kaitannya dengan pembentukan nasionalisme dan identitas kebangsaan di daerah tersebut. Penelitian dilakukan dengan menggunakan pendekatan kualitatif, di mana pengumpulan data dilakukan melalui pengamatan, wawancara mendalam, dan diskusi kelompok terfokus (FGD). Lokus penelitian adalah Kota Atambua, Kabupaten Belu, Provinsi Nusa Tenggara Timur, yang terletak di daerah perbatasan Indonesia-Timor Leste. Hasil penelitian menunjukkan bahwa nasionalisme dan identitas kebangsaan di daerah tersebut sangat dipengaruhi oleh peristiwa pemisahan Timor Leste dari Indonesia pada 1999 dan dampak sosiologisnya yang masih dirasakan hingga saat ini. Media massa, khususnya yang lokal, melalui peliputan dan pemberitaan mereka, berperan dalam mengelola isu sosiohistoris ini di dalam kehidupan bermasyarakat.
\end{abstract}

Kata kunci: media massa, perbatasan RI-Timor Leste, nasionalisme, identitas kebangsaan.

\begin{abstract}
Mass media has an important role in shaping national identity, especially in Indonesia, which has an archipelagic territory. However, the discrepancy of the availability of access to mass media throughout Indonesia is still an obstacle to the effectiveness of mass media in serving its role. This article seeks to present an empirical description of mass media access in border areas in relation to the formation of nationalism and national identity in these areas. The research was conducted using qualitative approach, where data collection was carried out through observation, in-depth interviews, and focus group discussions (FGD). The research locus is the city of Atambua, Belu Regency, East Nusa Tenggara Province, which is located in the border area between Indonesia and Timor Leste. The results show that nationalism and national identity in the area were strongly influenced by the event of the separation of Timor Leste from Indonesia in 1999 and its sociological impact that is still being present today. The mass media, especially the local ones, through their coverage and reporting, play a role in managing this sociohistorical issue in social life.
\end{abstract}

Keywords: mass media, Indonesia-Timor Leste border, nationalism, national identity.

Correspondence author: Ernalem Bangun, ernabangun@yahoo.com

This work is licensed under a CC-BY-NC 


\section{PENDAHULUAN}

Media massa adalah media komunikasi dan informasi yang melakukan penyebaran informasi dan dapat diakses oleh masyarakat secara massal (Bungin). Dalam praktiknya, objektivitas media massa dalam menyampaikan suatu realitas kepada khalayak selalu menjadi bahan diskusi dan perdebatan. Hal ini karena media massa tidak mungkin tidak, selalu melakukan penafsiran, penyaringan, pemilihan, hingga simbolisasi terhadap realitas yang hendak disampaikan. Media massa pada awalnya dikenal dengan istilah pers, dari bahasa Belanda "pers" yang secara harfiah berarti "cetak," sehingga dapat dimaknai sebagai penyiaran atau publikasi secara tercetak. Dalam perkembangannya pers dapat diartikan secara sempit maupun luas. Pers dalam pengertian luas meliputi segala penerbitan, termasuk media massa elektronik (radio dan televisi), sedangkan dalam pengertian sempit terbatas pada media massa cetak saja, yakni surat kabar, majalah, dan buletin (Effendy).

Media massa di Indonesia memiliki sejarah yang cukup panjang. Radio merupakan media massa elektronik yang paling mula ada. Masyarakat Indonesia pertama kali mendengarkan siaran radio (radio Vereenigingen) pada tahun 1920 (Yuliani et al.). Pada masa pemerintahan kolonial Hindia Belanda, Gubernur Jenderal de Fock telah meresmikan pemancar radio Malabar di Bandung pada 5 Mei 1923, dan pada 11 Maret 1927, pemerintah Belanda melakukan percobaan siaran radio gelombang pendek (shortwave/SW) melalui pemancar dari laboratorium Philips di Eindhoven, Belanda, ke Hindia Belanda. Saat itulah Belanda terhubung dengan Hindia Belanda melalui jaringan radio. Dua puluh hari kemudian, Ratu Wilhelmina menyapa rakyat di Hindia Belanda dari laboratorium radio Philips. Siaran internasional yang dipancarkan secara langsung pada 31 Maret 1927 itu berhasil ditangkap di Australia, Amerika Latin, Afrika, dan Asia Tenggara, termasuk di Pura Mangkunegaran Surakarta (Wanhar).

Pada masa revolusi (1945-1949), bermunculan radio-radio perjuangan, termasuk Radio Pemberontakan di Surabaya, Malang, dan Solo, di mana Bung Tomo mengobarkan semangat perjuangan; Radio Internasional Indonesia di Kediri; Gelora Pemuda di Madiun; Radio Militer dan Radio Indonesia Raya di Yogyakarta; Radio Perjuangan di Semarang; Rimba Raya di Aceh. Selanjutnya, Radio Republik Indonesia (RRI) secara resmi didirikan pada tanggal 11 September 1945 oleh para tokoh yang sebelumnya aktif mengoperasikan stasiun radio Jepang di enam kota (Wanhar).

Media massa cetak di Indonesia bahkan memiliki sejarah yang jauh lebih panjang lagi. Di Semarang, misalnya, pada tahun 1845 badan media massa milik Belanda (Oliphant en Compagnie) telah menerbitkan surat kabar mingguan bernama Semarangsch Nieuws en Advertientibald, yang di kemudian hari berganti nama menjadi De Locomotif dan terbit harian. Selain itu, pada tahun 1860 bahkan telah terbit surat kabar berbahasa Melayu yang bernama Selompret Melayu, diterbitkan mingguan oleh dewan Gereja Protestan (Wijaya 24).

Dalam sejarahnya, pembentukan negara-bangsa Indonesia juga tidak dapat dipisahkan dari peran yang dimainkan oleh media massa. Pada masa-masa awal kebangkitan nasional, media cetak menjadi wahana bagi tokoh-tokoh pergerakan untuk menyebarluaskan ide-ide kebangsaan. Selain itu, segera setelah proklamasi kemerdekaan 17 Agustus 1945 radio juga menjadi corong utama penyebarluasan berita mengenai kemerdekaan Indonesia. Di Jakarta, studio radio Hosokjoku yang dikuasai 
Jepang menyiarkan proklamasi kemerdekaan Indonesia. Kota-kota lain di Indonesia, seperti Yogyakarta, Bandung, dan Surabaya, juga dapat dalam waktu relatif singkat menerima berita tentang proklamasi kemerdekaan berkat adanya siaran radio (Yuliani et al.).

Dari masa ke masa, media massa terus mengalami perubahan, dan memiliki dampak signifikan baik positif maupun negatif dalam kehidupan bermasyarakat, berbangsa, dan bernegara di Indonesia. Di antara dampak positifnya, masyarakat mendapatkan informasi tentang masalah di berbagai bidang seperti sosial, politik, ekonomi, dan teknologi, baik dari dalam maupun luar negeri. Berbekal informasi tersebut, masyarakat akan dapat mengambil tindakan-tindakan dan keputusankeputusan untuk menghadapi perubahan situasi di sekitar mereka.

Adapun dampak negatif media massa kerap muncul manakala kepentingan politik berjalin kelindan dengan penguasaan kapital di tangan segelintir pemilik media massa. Akibatnya, informasi yang disampaikan kepada masyarakat bias dan tidak berimbang. Terlebih pada era demokrasi saat ini, media massa kerap menjalin afiliasi, baik terang-terangan maupun sembunyi-sembunyi, dengan kepentingan politik tertentu, terutama untuk membingkai suatu isu dan membentuk opini publik sehingga menguntungkan kepentingan politik yang disokongnya. Namun demikian, jalin kelindan antara media massa dengan kepentingan politik bukanlah hal yang baru sama sekali. Bahkan pada masa Demokrasi Terpimpin (1959-1965), Presiden Soekarno memanfaatkan Persatuan Wartawan Indonesia (PWI) untuk menghantam lawan-lawan politiknya. Adapun selama masa pemerintahan Orde Baru, media massa secara tidak langsung turut menyokong rezim developmentalisme yang dijalankan pemerintah pada waktu itu melalui penyiaran-penyiaran tentang kemajuan pembangunan nasional (Wijaya 24).

Perkembangan media massa yang sudah sangat pesat di berbagai kota besar di Indonesia, pada kenyataannya belum diimbangi dengan pembangunan sarana dan prasarana telekomunikasi di berbagai daerah perbatasan. Pembangunan infrastruktur telekomunikasi di daerah-daerah perbatasan masih sangat kurang, sehingga masyarakatnya lebih mudah menangkap siaran dari negara tetangga (Irdayanti). Sulitnya akses media massa di wilayah perbatasan berdampak pada terbatasnya informasi/berita-berita nasional. Padahal, berita-berita nasional mempunyai andil besar dalam membangun pengetahuan masyarakat mengenai negaranya-membangun kesadaran akan negara sebagai sebuah "komunitas yang dibayangkan" (imagined community) (Anderson), dan dengan demikian, memperkuat identitas kebangsaan.

Oleh karena itu, akses media massa di wilayah perbatasan sangat diperlukan guna menjaga rasa nasionalisme, khususnya dengan membuka jaringan komunikasi dan informasi dari wilayah perbatasan ke seluruh wilayah Indonesia maupun sebaliknya. Penelitian ini dilakukan untuk menghimpun data empiris dan berdasarkan data tersebut, membangun pemahaman yang jernih tentang kondisi perkembangan media massa di daerah perbatasan Indonesia, khususnya dalam kaitannya dengan kepentingan pertahanan melalui penguatan dan pemeliharaan nasionalisme masyarakat perbatasan. 


\section{METODE}

Penelitian ini dilakukan dengan menggunakan pendekatan kualitatif. Teknik pengumpulan data yang digunakan meliputi pengamatan, wawancara mendalam, diskusi kelompok terfokus (focused group discussion/FGD), dan kajian kepustakaan. Pengamatan dan wawancara mendalam dilaksanakan selama penelitian lapangan di Kota Kupang dan Kota Atambua, Provinsi NTT, pada tanggal 10-14 September 2018. Penelitian ini sendiri merupakan bagian dari program penelitian dan pengembangan yang dilaksanakan oleh Tim Peneliti Pusat Litbang Strategi Pertahanan Badan Penelitian dan Pengembangan Kementerian Pertahanan RI (Puslitbang Strahan Balitbang Kemhan RI), dengan tajuk "Litbang Strategi Peningkatan Akses Media Massa di Wilayah Perbatasan guna Memperkokoh Nasionalisme." Secara keseluruhan, program litbang tersebut dilaksanakan dalam kurun satu tahun dengan lima situs penelitian, yakni DKI Jakarta, Kabupaten Belu (NTT), Merauke (Papua), Nunukan (Kalimantan Utara), dan Sanggau (Kalimantan Barat) pada tahun 2018.

Para informan penelitian terdiri atas pemangku kepentingan yang berada di berbagai lembaga dan instansi pemerintahan terkait, seperti Komisi Penyiaran dan Informasi Daerah (KPID) Provinsi NTT, Badan Nasional Pengelola Perbatasan (BNPP) di pos perbatasan Motaain, Badan Kesbangpol Kabupaten Belu, Dinas Komunikasi dan Informasi Kabupaten Belu, Satuan Binmas Polres Belu. Selain itu, data-data yang diperlukan juga dihimpun dari beberapa informan dari lembaga penyiaran publik seperti TV Belu dan RRI Belu, serta para jurnalis lokal, di samping juga informasi tambahan dari kalangan akademisi, yakni dari Sekolah Tinggi Ilmu Sosial dan Ilmu Pemerintahan (STISIP) Fajar Utama, Atambua.

Penulis mafhum bahwa daerah perbatasan darat Indonesia memiliki karakteristik dan permasalahan yang berbeda-beda, baik daerah perbatasan dengan Malaysia di Provinsi Kalimantan Barat (Kalbar), Kalimantan Timur (Kaltim), dan Kalimantan Utara (Kaltara), dengan Papua Nugini di Provinsi Papua, maupun dengan Timor Leste di Provinsi Nusa Tenggara Timur (NTT). Oleh karena itu, perlu diakui bahwa pembahasan dalam tulisan ini memiliki keterbatasan yang tidak memungkinkan dilakukannya generalisasi untuk menjelaskan kondisi akses media massa dan keterkaitannya dengan nasionalisme masyarakat setempat di seluruh daerah perbatasan di Indonesia. Hal ini mengingat data yang dianalisis dan dibahas dalam tulisan ini terbatas hanya pada data yang dihimpun dari lokus penelitian daerah perbatasan Indonesia-Timor Leste di Provinsi NTT.

\section{Gambaran Umum Lokasi Penelitian}

Kabupaten Belu merupakan salah satu kabupaten di Provinsi Nusa Tenggara Timur (NTT) yang berbatasan langsung dengan Timor Leste. Kabupaten Belu berdiri pada tanggal 20 Desember 1958 dengan Atambua sebagai ibu kota kabupaten. Luas wilayah Kabupaten Belu mencapai 1.284,94 km², yang secara administratif terbagi atas 12 kecamatan (BPS Kabupaten Belu). Beberapa kecamatan di antaranya berstatus sebagai daerah perbatasan, yakni Kecamatan Malaka Timur, Tasifeto Barat, Tasifeto Timur, Lamaknen, Rehaat, dan Kobalima (Bifel).

Berdasarkan laporan registrasi penduduk tahun 2016, penduduk Kabupaten Belu mencapai 207.170 jiwa, terdiri atas 102.751 laki-laki dan 104.419 perempuan. 
Adapun berdasarkan Survei Angkatan Kerja Nasional (Sakernas) 2015, angkatan kerja di Kabupaten Belu mencapai 93.254 orang (70,03 persen dari jumlah penduduk). Dari jumlah angkatan kerja tersebut, 66,25 persen berstatus bekerja (BPS Kabupaten Belu 61). Mayoritas penduduk di Kabupaten Belu beragama Katolik, yakni mencapai 88,47 persen (BPS Kabupaten Belu 109).

Berdasarkan Survei Sosial Ekonomi Nasional (Susenas) 2016, terkait bidang pendidikan, di Kabupaten Belu terdapat 245 sekolah yang terdiri atas 23 unit taman kanak-kanak (TK), 142 unit sekolah dasar (SD/MI), 46 unit sekolah menengah pertama (SMP/MTs), 22 unit sekolah menengah atas (SMA/MA), 9 unit sekolah menengah kejuruan (SMK), dan 3 unit akademi/perguruan tinggi. Persentase penduduk yang tidak memiliki ijazah (tidak/ belum sekolah dan tidak tamat SD) mencapai 27,08 persen, dengan angka buta huruf mencapai 4,54 persen untuk laki-laki dan 1,60 persen untuk perempuan (BPS Kabupaten Belu 109).

Terkait bidang kesehatan, hingga tahun 2016 terdapat 4 unit rumah sakit di Kabupaten Belu, termasuk RSUD Mgr. Gabriel Manek, SVD. Jumlah dokter umum di Kabupaten Belu sebanyak 23 orang, dokter ahli 11 orang, dan dokter gigi 4 orang (BPS Kabupaten Belu 109).

\section{HASIL DAN PEMBAHASAN}

Perkembangan sosial masyarakat Provinsi Nusa Tenggara Timur (NTT) pada umumnya, khususnya Kabupaten Belu, tidak terlepas dari konflik dan krisis sosialpolitik yang terjadi pada tahun 1999, ketika Timor Leste (Provinsi Timor Timur pada waktu itu) melakukan referendum dan memisahkan diri dari Negara Kesatuan Republik Indonesia (NKRI) sebagai sebuah negara baru. Sejak tahun 2002, Timor Leste pun memperoleh pengakuan dunia sebagai negara merdeka dengan nama resmi Republica Democratica de Timor Leste (RDTL). Oleh karena itu, peran media massa di daerah tersebut dalam kaitannya dengan penumbuhan rasa kebangsaan juga tidak terlepas dari peristiwa sejarah ini.

Para informan penelitian mengungkapkan, pada tahun 1999 ketika krisis sosialpolitik terjadi, media massa di NTT belum begitu berkembang, baik jumlah maupun jenisnya masih sangat terbatas. Pemberitaan tentang situasi krisis di Timor Timur pun, pada saat itu lebih banyak dilakukan oleh media-media massa nasional yang berbasis di Jakarta. Oleh karena itu, kendati masyarakat merasakan secara langsung dampak dari krisis yang terjadi, namun mereka relatif tidak terpapar oleh pemberitaan mengenai krisis tersebut. Media massa di tingkat lokal, baik berupa surat kabar, radio, maupun televisi, baru berkembang pada dasawarsa pertama 2000-an.

Seiring dengan berlangsungnya proses demokratisasi di Indonesia hingga ke tingkat lokal dan digalakkannya otonomi daerah, kebebasan berpendapat di ruang publik pun semakin terbuka. Secara institusional, hal ini ditandai dengan kemudahankemudahan yang diberikan oleh pemerintah, terutama menyangkut perizinan, bagi pendirian media-media massa lokal, khususnya radio. Oleh karena itu, informan dari KPID mengungkapkan, selama periode tersebut banyak bermunculan stasiun-stasiun radio baru. Namun demikian, sebagian besar dari stasiun-stasiun radio ini tidak berumur panjang. Hal ini karena sebagai sebuah industri, ternyata radio tidak cukup 
berkembang dan didukung pasar yang amat terbatas. Hingga saat ini, stasiun radio yang masih bertahan hanyalah RRI, sebagai lembaga penyiaran publik milik pemerintah.

Dalam perkembangannya, keberadaan RRI pun terkendala banyak hambatan. Salah satu yang utama adalah keterbatasan infrastruktur. Terutama di daerah perbatasan antara NTT dengan Timor Leste, Kepala RRI Kabupaten Belu menjelaskan, masih banyak daerah-daerah yang tidak dapat dijangkau sinyal radio. Hal ini dikarenakan keterbatasan daya yang dimiliki oleh pemancar RRI. Pada perkembangan terakhir, telah dibangun oleh Kementerian Komunikasi dan Informatika RI (Kemkominfo) pemancar baru dengan daya lima kali lebih kuat dari yang ada sebelumnya, yakni mencapai 5.000 Watt. Yang kemudian masih menjadi persoalan, tenaga listrik yang ada di daerah perbatasan tersebut belum mampu untuk mendukung operasionalisasi pemancar radio dengan daya sebesar itu. Persoalan infrastruktur semacam ini sebenarnya juga mengindikasikan adanya persoalan institusional, berupa kurangnya sinergi antar-lembaga pemerintah maupun pelaksana-pelaksana program pembangunan, yang pada aras makro merupakan implikasi dari kurang koherennya agenda pembangunan di tingkat nasional.

Padahal, kemampuan untuk melakukan siaran di daerah perbatasan dengan dukungan infrastruktur yang memadai merupakan hal yang signifikan bagi kelancaran pelaksanaan tugas RRI sebagai lembaga penyiaran publik. Khususnya, dalam upaya memperkuat kehadiran negara di daerah-daerah perbatasan melalui siaran-siarannya. Salah satu program acara yang saat ini telah dilaksanakan untuk menjalankan fungsi tersebut adalah Siaran Perbatasan dengan bekerja sama dengan Satgas Pengamanan Perbatasan (Pamtas) yang bertugas di daerah perbatasan NTT-Timor Leste. Program ini sedianya menyajikan siaran langsung dari titik-titik perbatasan. Akan tetapi, karena keterbatasan infrastruktur tadi, untuk saat ini program tersebut hanya dapat disiarkan dari studio RRI di Atambua, bukan dari daerah perbatasan langsung.

Siaran di daerah perbatasan sebenarnya penting, mengingat di banyak titik belum ada kesepakatan final antara pemerintah RI dengan Timor Leste menyangkut perbatasan kedua negara. Oleh karena itu, banyak daerah di kawasan perbatasan yang hingga saat ini masih menjadi sengketa. Kondisi ini tentu berimbas ke masyarakat yang tinggal di daerah perbatasan.

Sebagai contoh, pada 13 September 2018, Komandan Kodim 1605/Belu memberikan penjelasan bahwa telah terjadi insiden di daerah perbatasan, di mana warga Indonesia diusir oleh tentara Timor Leste. Padahal, para warga yang diusir tersebut masih berada di dalam wilayah kedaulatan NKRI. Beberapa waktu sebelumnya juga terjadi insiden di mana helikopter sewaan warga Timor Leste terbang rendah tanpa izin di wilayah kedaulatan NKRI. Akibatnya, sebagai bentuk ketegasan sikap, Komandan Korem 161/Wirasakti memerintahkan agar pengamanan di daerah perbatasan diperketat.

Komandan Kodim 1605/Belu menunjukkan kepada Tim Peneliti bahwa pada insiden-insiden di daerah perbatasan semacam ini, stasiun televisi Timor Leste gencar membuat pemberitaan-pemberitaan yang tentu saja akan menguntungkan perspektif mereka. Dengan "bungkamnya" pemberitaan dalam negeri, isu-isu semacam ini tentu akan mudah berkembang menjadi isu yang tidak berimbang dan memengaruhi opini publik, khususnya publik internasional, dalam memandang permasalahan perbatasan antara RI dan Timor Leste. Jika dibiarkan, hal semacam ini tentu akan berpotensi merugikan kepentingan nasional RI. 
Kondisi sosial lain yang masih terjadi dan merupakan dampak dari krisis sosialpolitik tahun 1999 adalah keberadaan warga eks-Timor Timur (eks-Timtim) yang kini tinggal sebagai warga negara Indonesia di berbagai daerah di Provinsi NTT. Di Kota Kupang, sebagaimana dijelaskan oleh para informan dari KPID, keberadaan warga eksTimtim yang belum dapat membaur sepenuhnya dengan warga masyarakat lokal telah menimbulkan berbagai bentuk kerawanan sosial. Hal ini salah satunya disebabkan masih terpisahnya daerah-daerah permukiman warga eks-Timtim dengan daerahdaerah permukiman warga lokal, yang sebagai akibatnya, muncul konsekuensi tak terduga (unintended consequences) berupa segregasi di antara kedua kelompok masyarakat.

Studi yang dilakukan oleh SNPK-THC (Sistem Nasional Pemantauan KekerasanThe Habibie Center) pada tahun 2014 di Ambon menunjukkan bahwa segregasi permukiman di daerah pasca-konflik telah menghambat keberhasilan rekonsiliasi dan pembauran antarkelompok masyarakat, sehingga menimbulkan kerawanan-kerawanan yang sewaktu-waktu berpotensi meletup sebagai konflik sosial baru (Ansori et al.). Fenomena serupa juga terjadi di Kupang, di mana insiden-insiden kecil yang melibatkan warga eks-Timtim kerap memantik konflik antarkelompok warga lokal dengan warga eks-Timtim. Selain itu, potensi konflik ini juga terlihat sifat latennya dari adanya sebutan "Tiles" (Timor Leste) yang ditujukan kepada para warga eks-Timtim, khususnya di wilayah Kota Kupang. Informan dari KPID mengungkapkan, sebutan "Tiles" ini merupakan pelabelan yang berkonotasi negatif, sehingga cukup sensitif untuk digunakan dalam komunikasi. Oleh karena itu, media massa yang ada di Kupang relatif memiliki pemahaman dan kesadaran untuk tidak pernah memunculkan istilah tersebut di dalam pemberitaan-pemberitaan mereka, terutama pemberitaan yang meliput konflik antarkelompok warga lokal dengan eks-Timtim.

Hasil pengumpulan data di Atambua menunjukkan bahwa kondisi sosial di kota tersebut relatif lebih stabil daripada di Kota Kupang, dalam kaitannya dengan keberadaan kelompok warga masyarakat eks-Timtim. Stigmatisasi "Tiles" relatif tidak ditemukan di Atambua. Selain itu, konflik antarkelompok yang melibatkan warga lokal dengan warga eks-Timtim juga hampir tidak pernah terjadi. Kalaupun terjadi, sifatnya konflik personal, bukan konflik antarkelompok. Para informan dari STISIP Fajar Timur Atambua mengungkapkan, terdapat beberapa faktor yang memengaruhi kondisi sosial yang relatif stabil ini.

Pertama, tidak seperti di Kupang, di Atambua warga eks-Timtim telah tinggal secara membaur dengan warga lokal, sehingga tidak ada lagi segregasi daerah-daerah permukiman berdasarkan pembedaan eks-Timtim dan lokal. Hal ini menyebabkan interaksi di antara kelompok-kelompok masyarakat yang berbeda ini pun lebih positif, sehingga mendorong terciptanya integrasi sosial. Kedua, dari segi etnisitas, warga lokal Atambua banyak yang masih satu suku bangsa dengan warga eks-Timtim, yakni suku bangsa Timor. Mereka juga menggunakan bahasa daerah yang sama dalam percakapan sehari-hari, yakni bahasa Tetun. Bahasa daerah ini sebenarnya masih dituturkan pula oleh orang-orang Timor yang menjadi warga negara Timor Leste. Hanya saja, narasumber dari STISIP mengungkapkan, bahasa Tetun di Timor Leste saat ini telah banyak tercampur dengan bahasa Portugis, sementara bahasa Tetun di NTT banyak mengadopsi kosakata-kosakata dari bahasa Indonesia. Diperkirakan, perkembangan ini dalam jangka panjang akan menyebabkan bahasa daerah orang Timor di NTT dan Timor Leste menjadi kian berbeda. 
Kendati situasi sosial di Atambua relatif lebih stabil daripada di Kota Kupang, khususnya dalam kaitannya dengan relasi antarkelompok warga lokal dan eks-Timtim, namun sebagai kabupaten yang berbatasan langsung dengan Timor Leste, Kabupaten Belu menghadapi sebentuk kerawanan juga. Potensi kerawanan ini tidak terlepas dari stabilitas sosial-politik di Timor Leste. Setiap kali terjadi ketidakstabilan sosial-politik di negara tersebut, imbasnya dapat dirasakan secara langsung oleh masyarakat Kabupaten Belu sebagai masyarakat perbatasan. Misalnya saja, situasi yang memanas di Timor Leste selama masa pemilihan umum negara tersebut pada Mei 2018. Selama periode tersebut, para informan merasakan adanya peningkatan mobilitas warga Timor Leste bolak-balik ke Kabupaten Belu. Situasi semacam ini patut mendapatkan perhatian khusus. Sebab, jika sewaktu-waktu terjadi ketidakstabilan politik di Timor Leste, imbasnya akan dirasakan langsung oleh warga Belu.

Pada bentuk-bentuk kerawanan sosial yang digambarkan di atas, media massa dapat mengambil peran, baik dalam meningkatkan ketegangan sosial maupun dalam meredam ketegangan dan mendorong integrasi sosial. Salah satu contohnya terlihat dari media massa di Kupang yang secara sadar menghindari penyebutan "Tiles" di dalam pemberitaan mereka. Hal ini merupakan bentuk kesadaran untuk menghindari caracara pemberitaan yang justru dapat memicu eskalasi konflik. Selain itu, pemberitaan media massa juga dapat berkontribusi bagi terwujudnya integrasi sosial, misalnya dengan mengangkat liputan-liputan yang menyoroti agenda-agenda kegiatan yang dapat menyatukan kelompok-kelompok yang berbeda, seperti antusiasme merayakan kemerdekaan RI.

Terkait hal di atas, momentum seperti ASEAN Games 2018 sebenarnya merupakan momentum yang potensial untuk menumbuhkan rasa kebersamaan dan kebangsaan sebagai bangsa Indonesia. Namun disayangkan, sebagaimana diungkapkan oleh para informan, momentum tersebut tidak dapat diakses oleh kebanyakan masyarakat NTT, khususnya Kabupaten Belu. Hal ini dikarenakan siaran ASEAN Games harus diakses melalui siaran TV satelit berbayar. Padahal, jika memang dimaksudkan untuk menumbuhkan rasa kebangsaan, seharusnya liputan tentang para atlet nasional yang berlaga di ajang bergengsi tersebut dapat diakses dan dinikmati secara cuma-cuma oleh sebanyak-banyaknya warga masyarakat. Hal semacam ini kiranya dapat menjadi perhatian pemerintah ke depan.

Terakhir, tidak seperti di perbatasan antara Indonesia dengan Malaysia di Pulau Kalimantan, di mana ketimpangan sosial-ekonomi lebih menguntungkan Malaysia karena pembangunan mereka yang lebih maju, di perbatasan Indonesia-Timor Leste yang terjadi justru sebaliknya. Para informan senada mengungkapkan bahwa hingga saat ini laju pembangunan di Indonesia masih lebih maju daripada pembangunan di Timor Leste. Dengan demikian, warga Timor Leste cenderung lebih bergantung ke Indonesia, meski para informan juga menggarisbawahi bahwa dalam jangka panjang situasi tersebut dapat berbalik 180 derajat jika pemerintah Indonesia tidak lebih memperhatikan pembangunan di daerah perbatasan, khususnya perbatasan RI-Timor Leste.

Dari uraian di atas, terlihat bahwa persoalan identitas kebangsaan yang berkembang di daerah NTT, khususnya di perbatasan NTT-Timor Leste, lebih banyak menyangkut persoalan integrasi sosial di antara kelompok-kelompok masyarakat yang berbeda, khususnya di antara warga lokal dan warga eks-Timtim. Dengan demikian, peran media massa dalam peningkatan nasionalisme dan penguatan identitas 
kebangsaan, untuk konteks NTT, seyogianya difokuskan pada peran integrasi sosial, baik dengan menghindari pemberitaan-pemberitaan sensitif yang dapat menyulut konflik maupun dengan mengangkat pemberitaan-pemberitaan yang sifatnya inklusif dan mendorong pembauran di antara warga lokal dan warga eks-Timtim.

\section{SIMPULAN}

Perkembangan media massa di NTT tidak terlepas dari perkembangan dan sejarah sosial masyarakatnya yang mengalami krisis sosial-politik selama proses pemisahan Timor Timur dari NKRI pada 1999. Permasalahan nasionalisme dan identitas kebangsaan yang mengemuka di NTT, khususnya Kabupaten Belu, lebih dekat ke persoalan integrasi sosial mengingat banyaknya warga eks-Timtim yang kini tinggal sebagai warga negara Indonesia di daerah tersebut. Oleh karena itu, peran media massa dalam memperkokoh nasionalisme dan memperkuat identitas kebangsaan di perbatasan RI-Timor Leste seyogianya difokuskan pada upaya mendorong integrasi sosial.

\section{UCAPAN TERIMA KASIH}

Penulis mengucapkan terima kasih kepada Pusat Penelitian dan Pengembangan Strategi Pertahanan Badan Penelitian dan Pengembangan Kementerian Pertahanan Republik Indonesia (Puslitbang Strahan Balitbang Kemhan RI) yang telah mendanai penelitian ini. Penulis juga mengucapkan terima kasih kepada anggota tim peneliti, khususnya kepada Muhammad R. Damm yang juga telah memberikan banyak catatan dan saran untuk perbaikan draf awal artikel ini.

\section{DAFTAR PUSTAKA}

Anderson, Benedict. Imagined Communities: Reflections on the Origin and Spread of Nationalism. Verso books, 2006.

Ansori, Mohammad Hasan et al. Segregasi, Kekerasan Dan Kebijakan Rekonstruksi Pasca Konflik Di Ambon. The Habibie Center \& Sistem Nasional Pemantauan Kekerasan, 2014.

Bifel, Hironimus. "Data Perbatasan Darat Indonesia-Timor Leste." antaranews.com, antara, 2013. 27 Juli 2020.

BPS Kabupaten Belu. "Kabupaten Belu Dalam Angka 2017." BPS Kabupaten Belu, 2017. general editor, BPS Kabupaten Belu.

Bungin, Burhan. Sosiologi Komunikasi (Teori, Paradigma, Dan Discourse Teknologi Komunikasi Di Masyarakat). Kencana Prenada Media Group, 2006. 
Effendy, Onong Uchjana. Ilmu Komunikasi: Teori Dan Praktek. Remaja Rosdakarya, 2002.

Irdayanti, Irdayanti. "Membangun Ketahanan Informasi Di Daerah Perbatasan Indonesia." TOLERANSI: Media Ilmiah Komunikasi Umat Beragama, vol. 9, no. 2, 2017, pp. 135-151, doi:http://dx.doi.org/10.24014/trs.v9i2.4328.

Wanhar, Wenri. "Gelombang Sejarah Radio." 2014.

Wijaya, Deddy Wahyu. "Sejarah Radio Republik Indonesia Wilayah Semarang Tahun 1945-1998." Journal of Indonesian History, vol. 1, no. 1, 2012, pp. 23-29, https://journal.unnes.ac.id/sju/index.php/jih/article/view/2221.

Yuliani, Rita et al. "Perkembangan Radio Republik Indonesia (Rri) Cabang Palembang Tahun 2000-2015 (Sumbangan Materi Pada Mata Kuliah Sejarah Nasional Indonesia Vii)." Criksetra: Jurnal Pendidikan Sejarah, vol. 7, no. 1, 2018, https:// ejournal.unsri.ac.id/index.php/criksetra/article/view/5303. 